\title{
Electricity outages in Ghana: are Contingent Valuation estimates valid?
}

\author{
Authors: \\ Anthony Amoah, Department of Economics, Central University, Accra, Ghana, and Africa \\ Centre for Applied Economics and Policy Research, Accra, Ghana. Email: \\ aamoah@central.edu.gh
}

Silvia Ferrini, Centre for Social and Economic Research on the Global Environment (CSERGE), School of Environmental Sciences, University of East Anglia, Norwich, UK and Department of Political and International Sciences, University of Siena, Italy

Marije Schaafsma, School of Geography and Environmental Science, University of Southampton UK.

\begin{abstract}
:
African countries experience persistent and serious energy outages, but while multiple valuation studies provide estimates of the costs of electricity outages in high-income countries, evidence is scarce for lower- and middle-income countries. The few studies that assess the value of reliable energy supply rely on the contingent valuation method that is under wide scrutiny. This paper aims to provide new estimates of households' willingness to pay to reduce electricity outages for Ghana and contributes to the debate on the validity of contingent valuation results for energy reliability. Our results suggest that households are willing to pay GHS 67 (\$17) per month for reliable electricity supply, equivalent to $7 \%$ of respondents' income. The results of tests for hypothetical bias, WTP-WTA disparity and income effects suggest that the contingent valuation estimates from this study are robust and can support decision makers in prioritizing energy policies and investments.
\end{abstract}


Key words: Electricity supply, validity, Ghana, contingent valuation, WTA-WTP gap, hypothetical bias. 


\section{Introduction}

The lack of basic energy services for millions of people globally, with expected minimal changes and in some cases deterioration - in this situation in the future, is alarming (Kaygusuz, 2012). The number of reported power outages is rising globally: in the USA the average number of annual outages doubles every five years (Mukherjee et al., 2018) and in Europe, countries have experienced multiple energy blackouts since 2000 (de Noij et al. 2007). Energy conditions are particularly critical in Sub-Saharan Africa where only 43\% of the current population receives electricity (IEA, 2017). In Africa, in the last three decades over 620 million people have faced electricity blackouts (International Energy Agency 2015). In at least 25 countries including Ghana (Mensah et al., 2016), Nigeria (Aliyu et al., 2013), Kenya (Mukulo et al, 2014), Uganda (Buchholz and Silva, 2010; Gore, 2009) and South Africa (Inglesi, 2010; Inglesi-Lotz, 2011), this has led to 'energy crises' (World Bank, 2013). Recent projections confirm that about 515 million Africans will still lack access to electricity by 2030 (Dagnachew et al 2018).

Ghana has a steadily growing GDP and is constantly facing electricity problems (ISSER, 2005, Appiah 2018). In 2014, the electricity consumed per capita was $15 \%$ higher than 2012 , but the energy production was only 3\% higher than in previous years. Between 2012 and 2016 the default in load-shedding management (e.g. policies or tariffs to turn off equipment or reduce operational levels at times of system-wide peak demand) caused regular outages (Taale and Kyeremeh, 2016, Appiah 2018). Existing studies on the demand for electricity in Ghana suggest that increasing industrial efficiency will not be able to outweigh the increase in electricity demand resulting from economic (income and output) and demographic effects (Adom et al., 2011).

The government of Ghana is committed to close the energy supply-demand gap and aims to increase power generation capacity rapidly and achieve universal access to electricity by 2020 (Ministry of Energy, 2010). A key policy issue is that funds for investment in effective energy policies, including renewable energy, energy efficiency and new combinations of energy sources, 
that are needed to improve energy supply, are lacking (Cheng, 2010). In combination with the high costs required for large energy plants, this means that power markets have stagnated in Ghana and other Africa countries in recent years (Szabó et al., 2016). In Ghana, since the flow of subsidies is irregular, energy companies fail to deliver regular and secure energy services. The estimated costs to firms in Ghana ${ }^{1}$ range from $15 \%$ of returns as a result of outages (World Bank Enterprise database, 2013) to 10-30\% of returns due to energy insecurity (e.g. idle workers, spoiled materials, lost output, damaged equipment, restart costs) (Adenikinju (2005). Appiah (2018) reports that Ghana lost about 2\% of GDP in 2007, 2013 and 2014 due to the energy crisis. More than half of the companies in Ghana reduce the effect of outages by owning or sharing a private electricity generator. However, households also experience significant direct and indirect effects (Barnes et al, 2011). Households rely on energy for primary needs (e.g. refrigerator for the food, lightening) and leisure activities (e.g. mobile phones and radios). The lack of secure energy has detrimental effects on households' wellbeing and inhibits social and economic development (Barnes et al, 2011). Investments to improve electricity supply would help to achieve economic development and poverty alleviation (Dagnachew et al., 2018, Van der Zwaan et al., 2018).

As in the long run the costs of investments in electricity supply will have to be covered at least in part by consumers, robust and valid estimates of households' benefits of, and willingness to pay for, ensuring reliable and sustained energy provision are required to inform governments and investors to assess the cost-recovery of energy investments. For high-income countries (HIC), the estimated direct and indirect costs to households, NGOs, firms, and transportation of recent blackouts (e.g. Texas in February 2011, see Baltimore 2011) are substantial (Kim et al., 2015; Praktiknjo, 2014; Reichl et al., 2013). Evidence from HIC shows that the perceived cost of blackouts for households represents about 3-15 percent of their income (e.g. Kim et al., 2015; Praktiknjo, 2014). However, evidence from lower- and middle-income countries (LMIC) of outage

\footnotetext{
${ }^{1}$ The average monthly number of electrical outages for firms is 8.4 in Ghana and 8.9 for Sub-Saharan Africa (SSA). Electrical outages in Ghana tend to be longer than average in SSA countries (7.8 vs 5.6 hours per day).
} 
costs for households and their preferences towards improving energy supply is scarce (cf. Taale and Kyeremeh, 2016).

Praktinjko et al. (2011) summarize the valuation methods used for valuing power outages and conclude that indirect effects of electricity blackouts cannot be captured by observational or macroeconomic models. Survey-based stated preference methods, such as the Contingent Valuation (CV) method, are the only alternative to assess people's attitudes and stated behaviour (Praktinjko, 2014). The strength of such stated preference methods is their ability to assess the households' preferences for reliable power supply capturing both market losses (e.g. rotten food) and non-market losses (e.g. not being able to listen to music or use domestic appliances). However, despite the popularity of stated preference methods in valuing electricity outages, there is considerable debate about the reliability and validity of the resulting welfare estimates (as we discuss in Section 2) and therefore their relevance for decision-making (e.g., Desvousges et al., 2016; Haab et al., 2013; Kling et al., 2013; Johnston et al., 2017). Increase in electricity outages and greater attention to household energy security require sound and robust estimates, yet few stated preference studies test the validity of results (see for overviews, Kim et al., 2015 and Morrissey et al., 2018).

This paper has two interlinked objectives. First, it aims to provide new and robust empirical estimates of the value of secure electricity supply for households in Ghana (a LMIC) using the CV method in order to include both market and non-market losses of black-outs. Second, we aim to empirically conduct three validity tests to address critique on CV by Hausmann (2012): hypothetical bias (external validity), the divergence between willingness to pay (WTP) and willingness to accept (WTA), and income effects (theoretical validity). The second aim supports the first aim: only WTP and WTA estimates that pass validity tests provide more robust information for energy policy.

The rest of the paper is organized as follows. Section 2 first provides an overview of studies of the economic (market and non-market) costs of electricity outages, then discusses critical 
methodological issues in CV studies, and finally assesses to what extent the empirical stated preference literature on electricity outages has addressed these issues. Section 3 explains the survey design. Section 4 presents the main results, which are discussed in Section 5. Section 6 presents the conclusions, and policy recommendations. Our findings suggest that households have a positive WTP of GHS 67 (\$17) per month, and these results are robust to validity tests.

\section{Literature review}

\subsection{Economic costs of outages in Ghana and other LMIC}

Electricity outages produce direct and indirect losses to households and firms and can have detrimental effects on social and economic development of African countries (Dagnachew et al., 2018). As there is no market where energy consumers can buy secure energy supply, the marginal cost of electricity outages needs to be estimated using specific economic valuation strategies. Three main alternatives exist (De Noij et al., 2007): direct methods (e.g. production function approaches), survey-based approaches (e.g. contingent valuation) and case specific applications. Direct methods require statistical information on the consequences of outages through lost production, defensive expenditures on backup facilities or sectorial input-output matrices (e.g. Jamasb et al 2012). These methods are particularly suitable to value energy security for firms as the statistical information is readily available especially in HIC. However, the application of these methods to estimate costs borne by households overlooks the loss of non-market opportunities for leisure time. Survey-based methods determine the respondents' willingness to pay for avoiding electricity outages and as a consequence capture both market and non-market losses. While the method is applicable to firms and households, doubts persist on the validity of the results for electricity outages (de Noij et al., 2007). Case specific applications like after event lists of losses and costs have been used in some countries (e.g. Praktinjko et al., 2011), but their applicability to other sectors or countries is mainly undermined by data availability. The methodological choice for estimating the value of electricity 
outages for households in LMIC is therefore mainly driven by data availability; survey based methods such as CV are frequently the only option as they rely on primary data collection.

Multiple CV studies exist on electricity outages from HIC, with more recent examples including Cohen et al. (2018), Breit et al. (2016), Ozbalfi and Jenkins (2015), Hensher et al. (2014) and Carlsson and Martinson (2008). Evidence from LMIC is scarcer. Besides two studies conducted in Ghana (Taale and Kyeremeh, 2016; Twerefou, 2014), in other LMIC a number of electricity-related WTP studies have been conducted, including Abdullah \& Jeanty (2011), Abdullah and Markandya (2012), Adenikinju (2005), Aravena et al. (2012), Gunatilake et al. (2012), Oliver et al. (2011), and Zhang and Wu (2012), as well as some W'TA studies (Hosking, 2012; du Preez et al., 2012, Hosking et al., 2015).

Twerefou (2014) conducted a CV survey in three regions (Greater Accra, Ashanti and Northern Regions) of Ghana and results show that households are willing to pay $\mathrm{GH} \not 0.3 / \mathrm{KWh}$. This represents one and a half times more than current energy expenses. The CV study by Taale and Kyeremeh (2016) on energy reliability in Cape Coast Metropolitan Area in Ghana found that the average household is willing to pay approximately GHф6.80 (US \$3.42) per month in addition to current payments, which represents $44 \%$ increase in the current energy expenditure and corresponds to $\mathrm{GH} \not 0.03 / \mathrm{KWh}$. In both studies income, age, education and other socio-economic variables are statistically significant factors explaining variation in WTP, but more importantly, the range of estimated additional payments, from a $44 \%$ and $150 \%$, is wide. These estimates might differ due to empirical and methodological variations. Furthermore, we calculate that the value of electricity outages ranges from $\$ 24.10 / \mathrm{kwh}$ in HIC (e.g. Praktiknjo 2011) to $\$ 0.03 / \mathrm{kwh}$ in LMIC (Taal and Kyeremeh (2016). The wide range in WTP values from other LMIC CV studies compromises their application to Ghana using a benefit transfer approach, as transfer errors could become unacceptably high. Moreover, because of the differences in the energy market and the 
institutional context, WTP estimates from existing studies are unlikely to provide reliable information for policy support in Ghana. We therefore develop a new CV study in Ghana.

\subsection{Validity of Contingent Valuation studies}

The reliability and validity of CV studies is heavily debated. Based on a comprehensive bibliography of over $7000 \mathrm{CV}$ studies, Carson (2012) is moderately positive about the usefulness of CV results, contrary to Hausman (2012) who casts doubt about the validity and reliability of empirical results. Earlier critiques by Diamond and Hausman (1993, 1994), Milgrom (1993) and McFadden and Leonard (1993) claimed that CV results are inconsistent with economic theory. Hanemann (1994) argued that the critiques on CV are based on inaccurate analysis of CV findings or unconventional interpretation of economic theory. The paper by Hausman (2012) revived the debate about CV, triggering responses from Haab et al. (2013, 2016) and Desvousges et al. (2016). While these authors support Hausman's recommendation that caution is needed when applying the CV method, they stipulate that CV can provide valid and policy relevant information. Haab et al. (2013) suggest that Hausman selectively reviewed the CV literature, while Desvousges et al. (2016) stress that the $\mathrm{CV}$ method needs more research and better empirical tests of reliability and validity. McFadden (2017) has argued that the CV methodology produces valid and reliable estimates for familiar non-market goods or services, and that more research is needed to understand the challenges to provide valid non-use value measures. In our study, we therefore focus on three points of critique: hypothetical bias, the divergence between WTP and WTA, and income effects (as an indicator of theoretical validity), which we briefly discuss here.

Hypothetical bias. Hausman (2012, p.44) defines hypothetical bias as "what people say is different from what they do". According to Loomis (2011), "hypothetical bias arises [..] when respondents report a W'TP that exceeds what they actually pay using their own money in laboratory 
or field experiments." Solutions for hypothetical bias can be classified in ex-ante and ex-post treatments (Loomis, 2011, 2014; Penn and Hu, 2018). Ex-ante solutions include appropriate survey protocols such as incentive compatible questions, cheap talk or a solemn oath. Carson and Groove (2007) suggest that binary question formats with clearly described consequences of the choice are incentive compatible. Cheap talk instruments warn respondents about the problem of overestimation due to hypothetical bias prior to their valuation of the good, or ask respondents who first overestimate their WTP to reconsider their choices in the following questions (Champ et al., 2009). The solemn oath involves a commitment to truth-telling before reporting WTP (Jacquemet et al., 2013). These strategies aim at increasing the credibility of the contingent scenario, thereby reducing the chance that respondents overstate the benefits. Ex-post treatments are mainly based on weighting or calibrating W'TP responses (Champ and Bishop 2001; Blumenschein et al., 2008; Weaver and Prelec, 2013). The calibration can be conducted by screening the data to control for "highly" abnormal responses (Loomis, 2014) or by combining WTP estimates with other observable price measures. Ex-ante and ex-post treatments can have statistically significant effects on WTP, but are no guaranteed solution to eliminate hypothetical bias (Whitehead and Cherry, 2007). Reducing hypothetical bias is important for CV studies on energy supply that want to provide robust estimates of WTP, for example, to set consumer prices or to calculate cost-recovery of investments.

WTP-WTA gap. Hausman (2012, p. 46) claims that "basic economic theory suggests that [WTP and WTA] approaches should give (approximately) the same answer, but both supporters and sceptics of CV methods recognize that large and persistent disparities commonly arise". The WTPWTA disparity has attracted great attention in the CV literature, but the issue remains unsettled (Hanemann, 1991; Diamond, 1996; Tuncel and Hammit, 2014; Kim et al., 2015). Some studies find WTA/WTP ratios ranging approximately from three to seven (Knetsch and Sinden, 1984; Bishop and Heberlein, 1986; Brookshire et al., 1986; Kahneman et al., 1990; Shogren et al., 1994; Horowitz 
and McConnell, 2002; Alberini and Khan, 2006), and we can argue that this disparity appears inconsistent with economy theory. Other studies report a WTA/WTP ratio of less than two, arguably coherent with economic neo-classical theory and explained by income elasticity (Coursey et al., 1987; Kachelmeier and Shehata, 1992; Boyce et al., 1992; Eisenberger and Weber, 1995; Haab et al., 2013). Horowitz et al (2013) and Kim et al. (2015) argue that Hausman (2012) uses too stringent neo-classical parameters to investigate the WTP-WTA gap and ignores the theoretical developments that may explain WTP-WTA differences. Evidence shows that W'TP is more likely to diverge from WTA when the good under investigation is associated with higher income elasticity, lower elasticity of substitution with other goods or is less akin to an ordinary good (Willig, 1976; Hanemann, 1991; Horowitz and McConnell, 2012; Tuncel and Hammit, 2014; Kim et al., 2015).

Income effects. Zawojska and Czajkowski (2015) suggest that construct validity tests, such as the sensitivity of WTP to theoretical variables (e.g. income), can provide a valid alternative to the adding up (scope sensitivity) test discussed by Hausmann (2012). Basic neo-classical economic theory posits that WTP is constrained by income, and therefore respondents with higher income are expected to state higher WTP. The magnitude of income effects varies across CV study designs and goods under valuation (Schlapfer, 2006; Barbier et al., 2017). However, for a private consumption good such as energy, one would expect income to have a significant effect on WTP. This test also provides relevant policy information in case electricity supply is deemed to be a basic need that the government aims to make affordable for all household through subsidies where necessary. Nonetheless, surprisingly few studies in the stated preference literature on energy demand report income effects, as our review in the next section reveals.

\subsection{Validity and reliability of stated preference studies on energy outages for households}


Despite the increase in CV studies on electricity outages and household energy security (see Kim et al., 2015 and Morrissey et al., 2018), the overview in Table 1 shows that only fourteen existing CV studies on energy outages have tested for one or more of the three reliability and validity tests that we focus on and only two of these studies are conducted in LMIC. Strikingly, no existing study tests for hypothetical bias, and only four studies investigate the WTA-WTP gap. Hypothetical bias is particularly important for studies conducted in LMIC, as the CV evidence base from these countries is limited and may suffer from additional limitations (e.g. Whittington and Pagiola, 2012; Durand-Morat et al., 2015; Christie et al., 2012; Rakotonarivo et al., 2016).

\section{[Table 1 here]}

Four studies investigate the gap between W'TA and W'TP. Beenstock et al. (1998) estimate the value of power outages for Israeli households. Their WTA and WTP estimates differ but the authors do not report the ratio. Pepermans (2011) analyses the values of electricity outages for Flemish households using a choice experiment. Although the study does not derive the WTA/WTP ratio, it explores the heterogeneity in the gap using attitudinal questions. Praktiknjo (2014) finds on average a WTA/WTP ratio of two for electricity outages in Germany, which increases with the duration of the interruption. The author argues that this effect is due to an income substitution effect: the longer the outage lasts, the harder it is for richer households to cope with the loss of more valuable food or activities, so that richer households are willing to pay more.

Küfeoglu and Lehtonen (2015) study electricity outages for Flemish households. Their results suggest that WTA is more than 10 times higher than WTP, but the authors do not report the details of the survey instrument so the reliability of results cannot be verified. Moreover, income effects are not tested and so their estimates might not pass this theoretical validity test. 
The other studies in Table 1 test for income effects; in the majority of the studies these are positive and significant. Few studies find no significant income effects (Damigos et al., 2009; Baarsma and Hop, 2009; Nkosi and Dikgang, 2018).

\section{Survey Design, econometric analysis and tests}

Our CV study was administered in the Greater Accra Region (GAR) which has a population of 4 million inhabitants (1 million households) (GSS, 2012). 91\% of the GAR population lives in urban areas (roughly 955 thousand households) and $87 \%$ of households have access to the national electrical grid, the highest regional electrification level (GSS, 2013).

A stratified sampling scheme with six communities in ten districts was defined. Following Christie et al. (2012), ten local well-trained enumerators collected the data through a door-to-door survey in face-to-face interviews in February-March 2015. Three experienced supervisors coordinated the fieldwork and data entry. The enumerators explained to respondents (household heads) that the survey aimed to evaluate a 24-hour electricity service policy and was not motivated or funded by any political party or public institution. The script reminded respondents of their income constraints.

The survey design was based on a pilot in the GAR in different communities than included in the final sample, but with the same enumerators. The questionnaire was arranged in four sections: introduction questions, general utility-related questions, CV questions and socio-economic information. All respondents responded first to the WTP question before stating their WTA (Tab.2 for summary statistics). The WTP question had a dichotomous choice format (Yes or No question to a proposed bid level) followed by an open-ended question, formulated as:

"Assume your household is provided with 24-hour electricity supply, how much would your household be [at most] willing to pay per month as an increase in electricity bill?" 
The WTA question was formulated similarly:

"Assume your household is provided with 24-hour electricity supply, however, you experience shortages as today. How much will you accept as [minimum] compensation from the government per month?”.

The choice of using different elicitation formats for WTP and WTA was dictated by the pilot results. We found that respondents felt comfortable to express their WTP in a referendum setting but not in an open-ended format. The vector of WTP bid values was defined during the pilot study and ranged from GHS 10 (\$2.62) to 100 (\$26.25). However, respondents preferred to express their WTA in an open-ended format. Using a referendum format for the WTA question was impossible as WTA was influenced by many different household characteristics (e.g. age of head of the house, employment status), and therefore selecting a credible bid vector was impossible.

The maximum amount respondents are willing to pay and the minimum they are willing to accept $\left(\mathrm{WTP}_{\mathrm{i}}, \mathrm{WTA}_{\mathrm{i}}\right)$ for continuous 24 -hour service are the dependent variables in our models. The dependent variable is specified as:

$$
\mathrm{W}_{\mathrm{i}}=\alpha+\mathbf{X}_{i} \boldsymbol{\beta}+\mathrm{u}_{\mathrm{i}}
$$

where $\mathbf{W}_{i}$ refers to the WTP or WTA for respondent $i, \mathbf{X}_{i}$ is a vector of household characteristics and other control variables (e.g. community dummies), $\beta$ is the vector of coefficients to be estimated, $\alpha$ is the constant term, and $\mathrm{u}_{\mathrm{i}}$ is stochastic term with a standard normal distribution. Different linear-in-parameter models were tested, and we report the best fit models in Section 4. We control for potential starting point bias introduced by the dichotomous choice value considered in the WTP models. The tests of CV validity are carried out as follows.

\section{1) Hypothetical bias.}


We used a combination of treatments. During the survey (ex-ante), the enumerators aimed to ensure consequentiality by saying "energy reliability requires improvement to the electricity grid to ensure 24 electricity in your house and this survey will establish if residents in Greater Accra Region are supporting this improvement by paying an adequate price to the Electricity Company of Ghana". Since an ex-ante treatment does not provide full assurance for reducing hypothetical bias, we also screened the data ex-post. Using monthly household income and the stated WTP for the proposed consistent 24-hours service, the Rational income ratio $(\mathrm{Rr})$ was derived as follows:

\section{$\mathrm{Rr}=W T P /$ Income}

The $\mathrm{Rr}$ ratio represents the percentage of monthly income which the respondent is willing to allocate to energy expenses, assuming that income represents wealth and ability to pay. We create flags $(\operatorname{Rrx} \%)$ when the $\mathrm{Rr}$ is below $20 \%$ or $40 \%$ to account for possible hypothetical bias. We consider that responses higher than the thresholds might represent unrealistic values and signal hypothetical bias, as it is unlikely that households can allocate more than $40 \%$ or $20 \%$ of their income to their energy expenses. We test for hypothetical bias with the following hypothesis:

\section{$H 1: W T P(\operatorname{Rrx} \%)=W T P($ full sample $)$}

H1 is rejected when the mean WTP value of the full sample is statistically different from that of Rrx $\%$ sub-samples. T-tests for nested samples and a non-parametric Mann-Whitney test were used for H1. Furthermore, bootstrap confidence intervals for each subsample were calculated to control for non-independency in the WTP values of the different sub-samples (Bateman et al., 2008; Aravena et al., 2012).

\section{2) WTP versus WTA.}

Our null hypothesis for the WTP-WTA gap in our data is:

H2: $W T P=W T A$ 
$\mathrm{H} 2$ is tested statistically using the parametric t-test and non-parametric (Wilcoxon signed-rank) tests. Our study design allows us to use a within-subject test, which has more statistical power than a between-subject test (Moffatt, 2016). We analyse the distribution of the difference between WTP and WTA as measured by the Kernel density to investigate the magnitude of the gap across respondents. If this difference is substantially higher than two we support the claim that our estimates are not reliable, but if the difference is minimal, we maintain that estimates are in line with economic theory.

\section{3) Income effect}

The standard test for an income effect is its statistically equivalence to zero $\left(H 3: B_{\text {income }}=0\right)$ which is conducted by a T-test or Wald test on the income parameter.

\section{Sample characteristics and results}

The final sample includes 504 observations after 10 observations are excluded due to missing data (the response rate is $83.3 \%$ ). $65 \%$ of respondents are male, the average household size is four and $48 \%$ of respondents are married, consistent with census statistics (GSS, 2012). The average household monthly income is GHS 429 which is slightly lower than the national estimate of GHS 544 for the GAR (GSS, 2008). The average electricity bill is GHS 36, which represents $8 \%$ of the average income. $95 \%$ of respondents base family decisions on the head of household's choices. None of the respondents had experienced 24 hours electricity supply throughout the year.

\section{[Table 2 here]}

The mean WTP is GHS 67 (\$17.60) and mean WTA is GHS 90 (\$23.60). The mean WTP is about $86 \%$ higher than respondents' current electricity bill, which suggests a positive attitude towards improving the service, although hypothetical bias may have driven this figure upwards. The mean 
WTA is more than twice as high as the current electricity bill (approx. 148\%). There were no zero or protest bids, indicating the importance of overcoming electricity outages to respondents' private lives and business interests.

In order to validate the WTP estimates, we test $\mathrm{H} 1$ for hypothetical bias. Table 3 reports the test results when responses are capped at $\mathrm{Rr}=40 \%(\mathrm{n}=375)$ and $20 \%(\mathrm{n}=206)$. At $40 \%$, the WTP estimates of the full sample and subsample are statistically similar, rejecting the presence of hypothetical bias. With the more stringent 20\% threshold, we detect hypothetical bias.

\section{[Tab. 3 here]}

To test H2, we model WTP and WTA responses as a function of socio-economic variables. Table 4 reports the log-log regression results of WTP and WTA functions for the full sample and the two Rr sub-samples. The models include control variables for community effects and robust standard errors to account for possible heteroscedasticity.

The models are statistically significant. Income is highly significant which provides evidence of the theoretical validity of our results. Our estimated income elasticity is in line with previous CV findings from HIC and LMIC studies on electricity outages and confirms that energy is a necessary good (e.g. Abdullah and Mariel, 2010; Gunatilake et al., 2012; Twerefou, 2014; Taale and Kyeremeh, 2016).

The other coefficients are in line with expectations. In a society of male-controlled household budgets, the households headed by males tend to have a significantly higher WTP probably because men are authorised to approve higher payments by themselves. The effect of household size is positive and significant in all models which reflects a higher dependency on reliable energy supply. Larger families for example store more food and outages might produce greater losses.

The respondents' current electricity bill is only significant in the WTP model for $\operatorname{Rr} \leq 20$, i.e. the sub sample with WTP lower than $20 \%$ of household income, suggesting that current energy 
expenditure is not a determinant of WTP and W'TA for electricity outages. Marital status is a significant factor of WTP but not of WTA. The parameter of Bid, the initial bid for the dichotomous choice WTP format that all respondents answered first, is positive and significant indicating significant starting point bias (e.g. Boyle et al., 1997).

\section{[Table 4 here]}

The disparity between mean WTP and WTA (H2) is tested by comparing sample observed means using a within-sample t-test and a Wilcoxon signed-rank test (see Table 5). The same tests are applied to compare predicted means that are based on the regression coefficients and include the effect of socio-economic factors.

\section{[Table 5 here]}

Table 5 shows that the mean WTA/WTP ratio is higher than one but not higher than two, with a divergence quite close to zero as shown in the Kernel density distribution in Figure 1.

\section{[Figure 1 here]}

Based on the results of our hypotheses tests, we claim that our estimates are in line with the utilitymaximizing models discussed by Willig (1976) who justifies a minor degree of divergence by income elasticity effects.

\section{Discussion}

Our results contribute to the evidence base for the estimated costs of electricity outages in LMIC borne by households, and in particular in Ghana. Respondents in Greater Accra, Ghana, are willing to pay for 24-hour domestic electricity supply and express to bear costs if supply is not reliable. Households are on average willing to pay $\mathrm{GH} \not 67$ per month (\$17) or GHф0.09/KWh, which is equivalent to around $7 \%$ of respondents' income. At GHф 82.46 per month or $0.11 / \mathrm{KWh}$, our 
WTA estimates are slightly higher than WTP but still comparable to previous findings. In fact, our CV estimates are larger than Taale and Kyeremeh (2016) who estimated WTP at GHф 0.03/KWh but smaller than the estimated GHф 0.3/KWh in Twerefou (2014). Also, our WTA estimates are smaller than in Twerefou (2014). Our WTP estimates for households are smaller than estimates from small and medium enterprises (Ghosh et al., 2017). We claim that our estimates are more robust than previous findings, as our results pass three validity tests and thus reject the main criticisms on CV methods, making our results more suitable for uptake in energy decision making.

Our study also contributes to the debate on CV validity and provides evidence to justify the use of the CV method for assessing energy outage costs. Our test results of hypothetical bias and the WTA-WTP gap, based on rigorous within-sample tests, suggest that the survey responses comply with theoretical expectations. Respondents had experience of electricity outages, which reduces the risk of "the potential error induced by not confronting any individual with the real situation" (Rowe et al., 1980, p.6). Based on an outlier test, where WTP outliers are defined on the basis of the expenses percentage of household income, we argue that only if respondents who express a WTP for electricity exceeding $20 \%$ of their income are excluded, our results are biased. Furthermore, our comparison of WTP and WTA results suggests only a minor divergence that is coherent with economic theory and potentially linked to income elasticity. The significance of income in our models provides further evidence to the theoretical validity of our findings.

However, we find significant starting point bias due to the bid vector of the dichotomous choice W'TP question. This finding might explain the difference between our results and previous findings: Twerefou (2014) employs a dichotomous choice WTP question and Taale and Kyeremeh (2016) an open-ended WTP question. Open-ended questions are more easily influenced by extreme bidders (stating very low or very high WTP amounts) whereas dichotomous choice questions are sensitive to the bid vector and hypothetical bias. 
Our results support the application of $\mathrm{CV}$ for energy outages and provide a counter-argument against the negative claims about the reliability and validity of CV studies and stated preference studies more broadly (e.g. McFadden and Train, 2017). As Ferrini and Turner (2018) clarify, such doubts are often casted mainly in relation to the valuation of non-use value components of unfamiliar environmental goods. While rigorous survey design (Johnston et al., 2017) and testing of CV studies remains paramount, our evidence suggests that CV studies can provide credible results (Ferrini and Turner, 2018).

\section{Conclusion and Policy implications}

Our findings are relevant to support investment decisions in reliable energy supply in Ghana and other lower- and middle-income countries. Households are willing to support investment in energy production for modern energy systems. A rough estimation of the WTP aggregated over the population of Greater Accra of 1 million households would suggest that increasing electricity bills would generate GHф804 million annually. These figures suggest that increased efforts in revenue collection would help to overcome the limited funds available for investment in energy plants and other sources, maintenance and expansion activities and address the problem of persistent, frequent and unpredictable electric power outages. However, decision makers need to carefully consider alternative energy scenarios for future investments, as improved energy access needs to be coupled with energy efficiency and renewable energy production to mitigate the potential negative environmental impacts (Ouedraogo 2017).

To increase energy supply, the Volta River Authority (VRA), the major energy producer in Ghana, has entered into a joint venture with China's Shenzhen Energy Group to build a 2x350MW coal fired power plant at Ekumfi Aboano in the Central Region at an estimated cost of about US $\$ 1.5$ billion. The plan is to extend the capacity to 2000MW after 2020. However, the use of coal for energy production will have enormous costs for Ghana's natural environment, while Ghana is 
endowed with renewable energy resources (Appiah 2018). It has the largest man-made lake in the world, with an $8,502 \mathrm{~km}^{2}$ surface area and a total volume of $148 \mathrm{~km}^{3}$, which could make hydrological energy feasible. However, as hydrological electricity generation is highly dependent on weather, climate change has been estimated to lead to a decrease of about $10-20 \%$ of the current energy production levels (Cole et al., 2014; IEA, 2012). Ghana has committed to achieving renewable energy targets of 19 percent of installed capacity under the renewable energy policy of the Economic Community of Western African States (ECOWAS). Alternative energy sources that help reduce energy outages and support a long term sustainable social and economic development need to be considered for Ghana (Appiah, 2018; Gyamfi et al., 2015). Our study shows that households' WTP would provide an important source of co-funding, which could be directed towards renewable energy options with lower environmental effects. Future studies on WTP of electricity consumers could aim to establish whether consumers are willing to pay a premium to avoid environmental damages of energy production. 


\section{References}

Abdullah, S., Mariel, P. (2010). Choice experiment study on the willingness to pay to improve electricity services. Energy Policy, 38(8), 4570-4581.

Abdullah, S., Jeanty, P. W., 2011. Willingness to pay for renewable energy: Evidence from a contingent valuation survey in Kenya. Renewable and Sustainable Energy Reviews, 15(6), 2974-2983.

Abdullah, S., Markandya, A. (2012). Rural electrification programmes in Kenya: Policy conclusions from a valuation study. Energy for Sustainable Development, 16(1), 103-110.

Adenikinju, A.F. (2005). Analysis of the cost of infrastructure failures in a developing economy: The case of the electricity sector in Nigeria (Vol. 148). African Economic Research Consortium.

Adom, P.K., 2011. Electricity consumption-economic growth nexus: The Ghanaian case. International Journal of Energy Economics and Policy, 1(1): 18-31

Alberini A., Khan J. (2006). Handbook on Contingent Valuation. Edward Elgar Publishing.

Aliyu, A.S., Ramli, A.T., Saleh, M.A. (2013). Nigeria electricity crisis: Power generation capacity expansion and environmental ramifications. Energy, 61, 354-367.

Appiah M.O. (2018). Investigating the multivariate Granger causality between energy consumption, economic growth and CO2 emissions in Ghana. Energy Policy, 112, 198-208

Aravena, C., Hutchinson, W.G., Longo, A. (2012). Environmental pricing of externalities from different sources of electricity generation in Chile. Energy Economics, 34(4), 1214-1225.

Arrow, K., Solow, R., Portney, P., Leamer, E., Radner, R., Schuman, H. (1993). Report of the NOAA Panel on Contingent Valuation. Federal Register 58: 4601-614.

Baarsma B., Hop, J.P. (2009). Pricing power outages in the Netherlands. Energy, 34, 1378-1386.

Banerjee S., Murphy J.H. (2005). The scope test revisited, Applied Economics Letters, 12(10), 613-617.

Barbier, E.B., Czajkowski, M., Hanley, N. (2017). Is the income elasticity of the willingness to pay for pollution control constant?. Environmental and Resource Economics, 68(3), 663-682. 
Barnes, D.F., Khandker, S.R., Samad, H.A. (2011). Energy poverty in rural Bangladesh. Energy Policy, 39(2), 894-904.

Bateman, I.J., Carson, R.T., Day, B., Hanemann, W.M., Hanley, N., Hett, T., Jones-Lee, M., Loomes, G., Mourato, S., Ozdemiroglu, E., Pearce, D.W., Sugden, R., Swanson, J. (2002). Economic Valuation with Stated Preferences Techniques: a Manual. Edward Elgar, Cheltenham, UK.

Beenstock, M., Goldinb, E., Haitovsky, Y. (1998). Response bias in a conjoint analysis of power outages. Energy Economics, 20, 135-156.

Blass, A.A., Lach, S., Manski, C.F. (2010). Using elicited choice probabilities to estimate random utility models: preferences for electricity reliability. International Economic Review, 51(2), 421-440.

Bishop, R. C., \& Heberlein, T. A. (1986). Does contingent valuation work. Valuing environmental goods: An assessment of the contingent valuation method, 123-147.

Blumenschein, K., Blomquist, G.C., Johannsson, M., Horn, N., Freeman, P. (2008). Eliciting Willingness to Pay Without Bias: Evidence from a Field Experiment. Economic Journal, 118, 114 137.

Boyce, R.R., Brown, T.C., McClelland, G.D., Peterson, G.L., Schulze, W.D. (1992). An experimental examination of intrinsic environmental values as a source of the WTA-WTP disparity. American Economic Review, 82, 1366-1373.

Boyle K.J., Johnson F.R., McCollum D.W. (1997). Anchoring and Adjustment in Single-Bounded, Contingent-Valuation Questions. American Journal of Agricultural Economics, 79(5), 1495-1500

Breit J., Komatsu S., Kaneko S., Ghosh P.P. (2016). Evaluating households' preferences regarding reducing power outages in rural areas: cases in the Ganges Floodplain in Bangladesh. Environmental Development Sustainability, 18, 73-94.

Brookshire, S. D., Eubanks, L., Randall, A. (1986). Estimating option price and existence values for wildlife resources. Land Economics, 59, 1-15. 
Buchholz, T., Da Silva, I. (2010). Potential of distributed wood-based biopower systems serving basic electricity needs in rural Uganda. Energy for Sustainable Development, 14(1), 56-61.

Carlsson, F, Martinsson, P. (2007). Willingness to Pay among Swedish Households to Avoid Power Outages: A Random Parameter Tobit Model Approach. The Energy Journal, 28(1), 75-89.

Carlsson, F, Martinsson, P. (2008). Does it matter when a power outage occurs? A choice experiment study on willingness to pay to avoid power outages. Energy Economics, 30, 1232-45.

Carson, R.T., Groves T. (2007). Incentive and Informational Properties of Preference Questions. Environmental and Resource Economics, 37, 181-210.

Carson, R.T., Czajkowski, M. (2014). The Discrete Choice Experiment Approach to Environmental Contingent Valuation. In Hess and Daily (Eds.), Handbook of Choice Modelling. Edward Elgar, Cheltenham UK.

Champ, P.A., Bishop R.C. (2001). Donation Payment Mechanisms and Contingent Valuation: An Empirical Study of Hypothetical Bias. Environmental and Resource Economics, 19(4), 383-402.

Champ, P.A., Moore, R., Bishop. R.C. (2009). A Comparison of Approaches to Mitigate Hypothetical Bias. Agricultural and Resource Economics Review, 38, 166-80.

Cheng, C.C. (2010). A new NAMA framework for dispersed energy end-use sectors. Energy Policy, $38,5614-5624$.

Christie, M., Fazey, I., Cooper, R., Hyde, T., Kenter, J. (2012). An evaluation of monetary and nonmonetary techniques for assessing the importance of biodiversity and ecosystem services to people in countries with developing economies. Ecological Economics, 83, 67-78.

Cohen, J., Moeltner, K., Reichl, J., Schmidthaler, M. (2018). Valuing electricity-dependent infrastructure: An essential-input approach. Energy Economics, 73, 258-273

Cole, M.A., Elliot, R.J.R., Strob, E. (2014). Climate Change, Hydro-Dependency, and the African Dam Boom. World Development, 60, 84-98. 
Coursey, D., Hovis, J., Schulze, W.D. (1987). On the supposed disparity between willingness to accept and willingness to pay measures of value. Quarterly Journal of Economics, 102, 679-90.

Dagnachew, A.G., Lucas, P.L., Hof, A.F., van Vuuren, D.P. (2018). Trade-offs and synergies between universal electricity access and climate change mitigation in Sub-Saharan Africa. Energy Policy, 114, 355-366.

Damigos, D., Tourkolias, C., Diakoulaki, D. (2009). Households' willingness to pay for safeguarding security of natural gas supply in electricity generation. Energy Policy, 5, 2008-2017.

Desvousges W., Mathews K., and Train K. (2016). From Curious to Pragmatically Curious: Comment on 'From Hopeless to Curious? Thoughts on Hausman's 'Dubious to Hopeless' Critique of Contingent Valuation. Applied Economic Perspectives and Policy, 38(1), 174-182.

de Noij M., Koopmans C., Bijvoet C., 2007; The value of supply security The costs of power interruptions: Economic input for damage reduction and investment in networks. Energy Economics 29, 277-295

Diamond, P.A., Hausman, J.A. (1993). On contingent valuation measurement of nonuse values. In Contingent valuation: A critical assessment. Emerald Group Publishing, pp. 3-38.

Diamond P.A., Hausman, J.A. (1994). Contingent valuation: Is some number better than no number?. Journal of Economic Perspectives, 8, 45-64.

Diamond, P. (1996). Testing the Internal Consistency of Contingent Valuation Surveys. Journal of Environmental Economics and Management, 30(1), 337-347.

du Preez M., Menzies G., Sale M., Hosking S., 2012. Measuring the indirect costs associated with the establishment of a wind farm: An application of the contingent valuation method Journal of Energy in Southern Africa • Vol 23 No 1 • February 2012

Durand-Morat, A., Wailes, E.J, Nayga, R.M. (2015). Challenges of conducting contingent Valuation Studies in developing Countries. American Journal of Agriculture Economics, 98(2), 597-609.

Durbin, J. (1954). Errors in variables. Revue de l'institut International de Statistique, 23-32. 
Edjekumhene, I., Cobson-Cobbold, J. (2011). Low-Carbon Africa: Ghana. Christian Aid/KITE.

Eisenberger, R., Weber, M. (1995). Willingness-to-pay and willingness-to-accept for risky and ambiguous lotteries. Journal of Risk and Uncertainty, 10 (3), 223-233.

Energy Commission of Ghana (2013). National Energy Statistics, 2000 - 2012. Accra

Energy Commission of Ghana (2015). National Energy Statistics, 2005 - 2014. Accra

Ferrini, S., Turner, K.R. (2018). McFadden, Daniel and Train, Kenneth: Contingent valuation of environmental goods—a comprehensive critique. Journal of Economics, 125, 205-207.

Ghosh, R., Goyal, Y., Rommel, J., Sagebiel, J. (2017). Are small firms willing to pay for improved power supply? Evidence from a contingent valuation study in India. Energy Policy, 109, 659-665.

Gore, C. (2009). Electricity and privatisation in Uganda: The origins of the crisis and problems with the response. Electric Capitalism: Recolonising Africa on the Power Grid, 359-399.

GRIDCo. (2010). Ghana Wholesale Power Reliability Assessment, Final Report, March 2010.

GSS - Ghana Statistical Service (2008). Ghana Living Standards Survey Report of the Fifth Round [Accessed on 06/03/2016: http://www.statsghana.gov.gh/docfiles/glss5 report.pdf].

GSS - Ghana Statistical Service (2012). 2010 Population and Housing Census, Summary Report of Final Results. Sakoa Press, Ghana.

GSS - Ghana Statistical Service (2013). 2010 Population and Housing Census, Regional Analytical Report: Greater Accra Region. Sakoa Press, Ghana.

Gunatilake, H., Maddipati, N., Patail, S. (2012). Willingness to Pay for Good Quality, Uninterrupted Power Supply in Madhya Pradesh, India. ADB South Asia Working Paper Series No. 13. Mandaluyong City, Philippines.

Gyamfi, S., Modjinou, M., Djordjevic, S. (2015). Improving electricity supply security in GhanaThe potential of renewable energy. Renewable and Sustainable Energy Reviews, 43, 1035-1045. 
Haab, T. C., Interis, M.C., Petrolia, D.R, Whitehead, J.C. (2013). From Hopeless to Curious? Thoughts on Hausman's "Dubious to Hopeless" Critique of Contingent Valuation. Applied Economic Perspectives and Policy, 35(4), 535-612.

Haab, T.C., Interis, M.G., Petrolia, D.R., Whitehead, J.C., (2016). Interesting questions worthy of further study: our reply to Desvousges, Mathews, and Train's (2015) comment on our thoughts (2013) on Hausman's (2012) update of Diamond and Hausman's (1994) critique of contingent valuation. Applied Economic Perspectives and Policy, 38(1), 183-189.

Hanemann, W.M. (1991). Willingness to pay and willingness to accept: how much can they differ? The American Economic Review, 81(3), 635-647.

Hanemann, W.M. (1994). Valuing the Environment through Contingent Valuation. Journal of Economic Perspectives, 8(4), 19-43.

Hausman, J. (2012). Contingent valuation: from dubious to hopeless. The Journal of Economic Perspectives, 26(4), 43-56.

Hensher, D.A., Shore, N., Train, K. (2014) Willingness to pay for residential electricity supply quality and reliability. Applied Energy, 115, 280-292

Horowitz, J.K., McConnell, K.E. (2002). A review of WTA/WTP studies. Journal of Environmental Economics and Management, 44(3), 426-447.

Horowitz, J.K., McConnell, K.E., Murphy, J.J. (2013). Behavioral foundations of environmental economics and valuation. In Handbook on Experimental Economics and the Environment. Edward Elgar, pp. 115-156.

Hosking, J., du Preez, M., Sharp, G., 2015. Low-income resident's preferences for the location of wind turbine farms in the Eastern Cape Province, South Africa. Journal of Energy in Southern Africa, 26(3), 10-18.

Hosking, J. L. (2012). Generating Guidance on Public Preferences for the Location of Wind Turbine Farms in the Eastern Cape. Magister Commercii (Statistics) Thesis, Nelson Mandela Metropolitan University Port Elizabeth. 
IEA - International Energy Agency. (2012). Technology roadmap: Hydropower. Paris.

IEA - International Energy Agency, 2015. World Energy Outlook 2015, OECD/IEA, Paris.

IEA - International Energy Agency. (2017). Energy Climate and Change: World Energy Outlook Special Report, IEA.

Inglesi, R. (2010). Aggregate electricity demand in South Africa: conditional forecasts to 2030. Applied Energy, 87(1), 197-204.

Inglesi-Lotz, R. (2011). The evolution of price elasticity of electricity demand in South Africa: A Kalman filter application. Energy Policy, 39(6), 3690-3696.

ISSER - Institute of Statistical, Social and Economic Research. (2005). Guide to Electric Power in Ghana. First edition, Accra. Accessed on 04/10/2015: http://www.beg. Utexas.edu/energyecon/IDA/USAID/RC/Guide_to_Electric\%20Power_in_Ghana.pdf

Jacquemet, N., Joule, R.-V., Luchini, S., Shogren, J.F. (2013). Preference elicitation under oath. Journal of Environmental Economics and Management, 65(1), 110-132.

Jamasb et al. (2012) "Estimating the marginal cost of quality improvements: The case of the UK electricity distribution companies" Energy Economics 34, 1498-1506.

Johnston R.J., Boyle K.J., Adamowicz, W., Bennett, J., Brouwer, R., Cameron, T.A., Hanemann, W.M., Hanley, N., Ryan, M., Scarpa, R., Tourangeau, R., Vossler, C. (2017). Contemporary Guidance for Stated Preference Studies. Journal of the Association of Environmental and Resource Economists, 4(2): 319-405.

Kachelmeier, S.J., Shehata, M. (1992). Examining risk preferences under high monetary incentives: experimental evidence from the People's Republic of China. American Economic Review, 82, 1120 1141. 
Kahneman, D., Knetsch, J.L., Thaler, R.H. (1990). Experimental tests of the endowment effect and the Coase theorem. Journal of Political Economy, 1325-1348.

Kaygusuz, K. (2012). Energy for sustainable development: A case of developing countries. Renewable and Sustainable Energy Reviews, 16(2), 1116-1126.

Kim, J., Kling, C.L., Zhao, J. (2015). Understanding Behavioral Explanations of the WTP-WTA Divergence Through a Neoclassical Lens: Implications for Environmental Policy. Annual Review of Resource Economics, 7, 169-187.

Kling, C.L., List, J.A., Zhao, J. (2013). A dynamic explanation of the willingness to pay and willingness to accept disparity. Economic Inquiry, 51(1), 909-921.

Knetsch, J.L., Sinden, J.A. (1984). Willingness to pay and compensation demanded: Experimental evidence of an unexpected disparity in measures of value. The Quarterly Journal of Economics, 507-521. Küfeoglu, S., Lehtonen, M. (2015) Comparison of different models for estimating the residential sector customer interruption costs. Electric Power System Research, 122(20), 50-55.

Loomis, J.B. (2011). What's to know about hypothetical bias in Stated Preference valuation studies? Journal of Economic Surveys, 25(2), 363-370.

Loomis, J.B. (2014). 2013 WAEA Keynote Address: Strategies for Overcoming Hypothetical Bias in Stated Preference Surveys. Journal of Agricultural and Resource Economics, 39(1), 34-46.

Ozbafli A., Jenkins G.P., (2015) The willingness to pay by households for improved reliability of electricity service in North Cyprus Energy Policy 359-369

Ozbafli A., Jenkins G.P., (2016) Estimating the willingness to pay for reliable electricity supply: a choice experiment study Energy Econ. 443-452

McFadden, D., Leonard G.K. (1993). Issues in the Contingent Valuation of Environmental Goods: Methodologies for Data Collection and Analysis. In Hausman (Ed.), Contingent V aluation: A Critical Assessment. North Holland Press, pp. 165-215. 
McFadden, D. (2017). Stated Preference methods and their applicability to environment use and non-use valuations. In McFadden and Train (Eds.), Contingent Valuation of Environmental goods. A comprehensive critique. Edward Elgard, pp. 153.

Mensah, J.T., Marbuah, G., Amoah, A. (2016). Energy demand in Ghana: A disaggregated analysis. Renewable and Sustainable Energy Reviews, 53, 924-935.

Milgrom, P. (1993). Is Sympathy an Economic Value? In Hausman (Ed.), Contingent Valuation: A Critical Assessment. North Holland Press, pp. 417-442.

Ministry of Energy (2010). National Energy Policy. Government of Ghana, Accra.

Moffatt, P.G. (2016). Experimetrics: Econometrics for Experimental Economics. Palgrave Macmillan.

Morrisey, K., Plater, A., Dean, M. (2018). The cost of electric power outages in the residential sector: A willingness to pay approach. Applied Energy, 212, 141-150.

Mukulo, B.M., Ngaruiya, J.M., Kamau, J.N. (2014). Determination of wind energy potential in the Mwingi-Kitui plateau of Kenya. Renewable Energy, 63, 18-22.

Mukherjee S., Nateghi R.,Hastak M., 2018; A multi-hazard approach to assess severe weatherinduced major power outage risks in the U.S. Reliability Engineering and System Safety, 175, 283305.

Nerini, F.F., Tomei, J., To, L.S., Bisaga, I., Parikh, P., Black, M., Borrion, A., Spataru, C., Broto, V.C., Anandarajah, G., Milligan, B. (2018). Mapping synergies and trade-offs between energy and the Sustainable Development Goals. Nature Energy, 3(1), 10.

Nkosi N.P, and Dikgang, J. 2018; Pricing electricity blackouts among South African households. Journal of Commodity Markets 11 (2018) 37-47

Oliver, H., Volschenk, J., Smit, E., 2011. Residential consumers in the Cape Peninsula's willingness to pay for premium priced green electricity. Energy Policy, 39(2), 544-550.;

Ouedraogo N.S. (2017). Africa energy future: Alternative scenarios and their implications for sustainable development strategies. Energy Policy, 106, 457-471. 
Ozbafli, A., Jenkins, G.P. (2015). The willingness to pay by households for improved reliability of electricity service in North Cyprus. Energy Policy, 87, 359-369.

Ozbafli, A., Jenkins, G.P. (2016) Estimating the willingness to pay for reliable electricity supply: a choice experiment study. Energy Economics; 56, 443-52.

Penn. J.M., Hu, W. (2018). Understanding hypothetical bias: an enhanced meta-analysis. American Journal of Agriculture Economics, 1000(4), 1186-1206.

Pepermans, G. (2011). The value of continuous power supply for Flemish households. Energy Policy, 39, $7853-7864$.

Praktiknjo, A.J. H“ahnel, A., Erdmann G (2011). Assessing energy supply security: Outage costs in private households. Energy Policy, 39, 7825-7833.

Praktiknjo, A.J. (2014). Stated preferences based estimation of power interruption costs in private households: An example from Germany. Energy, 76, 82-90.

Pueyo, A. (2018). What constrains renewable energy investment in Sub-Saharan Africa? A comparison of Kenya and Ghana. World Development, 109, 85-100.

Rakotonarivo, O.S., Schaafsma, M., Hockley, N. (2016). A systematic review of the reliability and validity of discrete choice experiments in valuing non-market environmental goods. Journal of Environmental Management, 183, 98-109.

Reichl J., Schmidthaler, M., Schneider F. (2013). The value of supply security: The costs of power outages to Austrian households, firms and the public sector. Energy Economics, 36, 256-261.

Rowe, R.D., d'Arge, R.C., Brookshire, D.S., 1980. An experiment on the economic value of visibility. Journal of Environmental Economics and Management, 7(1), 1-19.

Schläpfer, F. (2006). Survey protocol and income effects in the contingent valuation of public goods: A meta-analysis. Ecological Economics, 57(3), 415-429. 
Schwerhoff, G., Sy, M. (2017). Financing renewable energy in Africa-Key challenge of the sustainable development goals. Renewable and Sustainable Energy Reviews, 75, 393-401.

Shogren, J.F., Shin, S.Y., Hayes, D.J., Kliebenstein, J.B. (1994). Resolving differences in willingness to pay and willingness to accept. The American Economic Review, 255-270.

Szabó, S., Moner-Girona, M., Kougias, I., Bailis, R., Bódis, K. (2016). Identification of advantageous electricity generation options in sub-Saharan Africa integrating existing resources. Nature Energy, 1(10), 16140.

Taale, F., Kyeremeh, C. (2016). Households' willingness to pay for reliable electricity services in Ghana, Renewable and Sustainable Energy Reviews, 62, 280-288.

Tuncel, T., Hammitt, J.K. (2014). A New Meta-analysis on the WTP/WTA Disparity. Journal of Environmental Economics and Management, 68, 175-187.

Twerefou, D.K. (2014). Willingness to Pay for Improved Electricity Supply in Ghana. Modern Economy, 5(5), 409.

Van der Zwaan, B., Kober, T., Dalla Longa, F., van der Laan, A., Kramer, G.J. (2018). An integrated assessment of pathways for low-carbon development in Africa. Energy Policy, 117, 387-395.

Weaver, R., Prelec, D. (2013). Creating Truth-Telling Incentives with the Bayesian Truth Serum. Journal of Marketing Research, 50, 289-302.

Whitehead, J.C., Cherry, T.L. (2007). Willingness to pay for a Green Energy program: A comparison of ex-ante and ex-post hypothetical bias mitigation approaches. Resource and Energy Economics, 29, 247-261.

Whittington, D., Pagiola, S. (2012). Using Contingent Valuation in the Design of Payments for Environmental Services Mechanisms: A Review and Assessment. The World Bank Research Observer, 27(2), 261-287. 
Willig, R.D. (1976). Consumer's surplus without apology. The American Economic Review, 66(4), 589597.

World Bank. (2013). Energy in Africa. Accessed on 06/02/2016: http://go.worldbank.org/63DZK29NW0.

Zhang, L., \& Wu, Y. (2012). Market segmentation and willingness to pay for green electricity among urban residents in China: The case of Jiangsu Province. Energy Policy, 51, 514-523.

Zawojska, E., Czajkowski, M. (2015). Re-examining empirical evidence on contingent valuation Importance of incentive compatibility. Working Papers from Faculty of Economic Sciences, University of Warsaw, No 2015-08. 